\title{
The Interface between the Area of Freedom, Security and Justice and the Common Foreign and Security Policy of the European Union: Legal Constraints to Political Objectives
}

\author{
Peter Van Elsuwege*
}

Work in progress - Please do not quote without permission from the author

\section{Paper prepared for the conference "Governance changes in the Area of Freedom, Security and Justice after the Lisbon Treaty, The Hague, 20-21 October 2011}

\begin{abstract}
This paper argues that the objective of increased foreign policy coherence, as expressed in the Treaty of Lisbon and the Stockholm Programme of the European Union (EU), faces significant legal obstacles. In particular, the blurred boundaries between situations falling within the EU's competence regarding the so-called Area of Freedom, Security and Justice (AFSJ), on the one hand, and its Common Foreign and Security Policy (CFSP) on the other hand, may give rise to inter-institutional turf battles. This is illustrated with the practice of adopting restrictive sanctions against individuals and non-State entities in the context of the EU's fight against terrorism.
\end{abstract}

\section{Introduction}

The Treaty of Lisbon reorganized the EU's competences and introduced a separate Title V on the establishment of an "Area of Freedom, Security, and Justice" (AFSJ) in the Treaty on the Functioning of the European Union (TFEU). ${ }^{1}$ According to Article 67 TFEU, EU action in this field pursues a wide range of objectives, including the absence of internal border controls, a common policy on asylum, immigration and external borders and a 'high level of security' through measures to prevent and combat crime, racism and xenophobia, increased coordination and cooperation between police and judicial authorities, mutual recognition of judgments in criminal measures and, if necessary, through the approximation of criminal laws. In other words, the AFSJ lacks a clearly identifiable policy objective and is rather an umbrella concept to link different subject matters related to the internal security of the European Union. ${ }^{2}$ Despite this internal orientation, it is obvious that threats to the internal security of the EU territory often originate outside the EU. Hence, the policy objectives of the

\footnotetext{
${ }^{*}$ Professor of European Law, Ghent University (Jean Monnet Centre of Excellence) and Post-Doctoral Research Fellow of the Research Foundation - Flanders (FWO).

${ }^{1}$ The new Title V includes provisions of the former first and third pillar (e.g. Article 67 TFEU combines former Article 61 EC and Article 29 TEU).

${ }^{2}$ N. Walker, "In Search of the Area of Freedom, Security and Justice: A Constitutional Odyssey”, in: N. Walker, (ed.), Europe's Area of Freedom, Security and Justice, Oxford: OUP, 2004, p. 7.
} 
AFSJ are closely linked to the EU's external policies such as the common commercial policy, the development policy and, foremost, the Union's Common Foreign and Security Policy (CFSP). ${ }^{3}$

Already in 1999, the Tampere European Council concluded that "all competences and instruments at the disposal of the Union, and in particular in external relations, must be used in an integrated and consistent way to build an area of freedom, security and justice." ${ }^{4}$ In 2005, the European Commission launched a "strategy on the external dimension of the Area of Freedom, Security and Justice”, aiming at a comprehensive approach to challenges such as terrorism, organized crime and drug trafficking. ${ }^{5}$ Finally, the more recent Stockholm Programme - an open and secure Europe serving and protecting citizens, adopted by the European Council after the entry into force of the Lisbon Treaty, reiterates the objective "to achieve greater coherence between external and internal elements of the work in the area of freedom, security and justice". ${ }^{6}$ In this respect, the European Council envisages better coordination between the policies in the AFSJ and the other external policies of the Union, including the Common Foreign and Security Policy (CFSP).

Despite the general political consensus that the internal and external aspects of EU security are inextricably linked, the complexity of the EU's institutional framework significantly hinders the coherence and efficiency of its actions. ${ }^{7}$ This was particularly the case in the pre-Lisbon situation, where external agreements and programmes were decided according to different procedures under the first, second and third pillars. The abolition of the pillar structure with the Treaty of Lisbon and institutional innovations such as the High Representative for Foreign Affairs and Security Policy and the European External Action Service all aim to enhance the coherence and consistency of the EU's external action. Nevertheless, the Common Foreign and Security Policy (CFSP) remains "subject to specific rules and procedures". ${ }^{8}$ This is highlighted by the fact that provisions on CFSP are included in Title V of the Treaty on European Union (TEU) whereas all other substantive areas of the EU's external action are laid down in Part V of the TFEU. The "mutual non-affectation clause" of Article 40 (ex 47, as amended) TEU confirms the importance of the distinction between the CFSP and the other policies of the Union. Hence, the division between different external policy areas remains crucial for the determination of the appropriate legal bases and decision-making procedures.

This article aims to scrutinize the implications of the new legal context for the external dimension of the AFSJ. After an overview of the most important innovations regarding the

\footnotetext{
${ }^{3}$ R. Wessel, L. Marin and C. Matera, "The External Dimension of the EU's Area of Freedom, Security and Justice”, in: C. Eckes and T. Konstadinides, (eds.), Crime within the Area of Freedom, Security and Justice: A European Public Order (Cambridge: CUP, 2011) , p. 277.

${ }^{4} \mathrm{http}: / /$ www.europarl.europa.eu/summits/tam_en.htm, para. 59.

${ }^{5}$ COM (2005) 491 final.

${ }^{6}$ European Council, "Stockholm programme - an open and secure Europe serving and protecting citizens”, OJ (2010) C 115/ 6.

${ }^{7}$ European Parliament report on an area of freedom, security and justice: Strategy on the external dimension, Action Plan implementing the Hague programme, A6-0223/2007.

${ }^{8}$ Art. 24 (1) TEU.
} 
EU's external action (II), specific attention is devoted to the adoption of restrictive sanctions against individuals. The legal framework of the EU's sanctions regime before the entry into force of the Treaty of Lisbon (III) is compared with the Lisbon provisions concerning the adoption of restrictive sanctions (IV). The remaining challenges for the coherence of the EU's external action are illustrated in the light of a pending inter-institutional conflict between the European Parliament and the Council concerning the adoption of amendments to Regulation 881/2001 imposing restrictive measures directed against certain persons and entities associated with Osama bin Laden, the Al-Qaida network and the Taliban. ${ }^{9}$ After discussing the potential solutions to this pending case (V), it is concluded that despite the formal abolition of the pillar structure, inter-institutional turf battles loom around the corner. Pragmatic inter-institutional cooperation will be required to solve the outstanding issues and to effectively enhance the coherence and consistency of the EU's external action (VI).

\title{
II. EU external action after Lisbon: Between Delimitation and Consistency ${ }^{10}$
}

In an attempt to increase the coherence and consistency of its policies, the Treaty of Lisbon introduced a number of significant innovations such as the formal abolition of the pillar structure (Art. 1 TEU), a single legal personality for the Union (Art. 47 TEU), a single set of foreign policy objectives (Art. 21 TEU) and new institutional actors (President of the European Council, High Representative for Foreign Affairs and Security Policy, External Action Service). Perhaps even more important than the institutional adaptations to increase the coherence of the EU's external action is the introduction of a new delimitation rule to distinguish between CFSP and non-CFSP external actions of the Union. Article 40 TEU lays down that:

\begin{abstract}
"The implementation of the common foreign and security policy shall not affect the application of the procedures and the extent of the powers of the institutions laid down by the Treaties for the exercise of the Union competences referred to in Articles 3 to 6 of the Treaty on the Functioning of the European Union.

Similarly, the implementation of the policies listed in those Articles shall not affect the application of the procedures and the extent of the powers of the institutions laid down by the Treaties for the exercise of the Union competences under this Chapter.”
\end{abstract}

This new rule stands in stark contrast to the hierarchic relationship between the pillars under the old treaty regime, where, inspired by a fear of intergovernmental contamination of supranational decision-making, several provisions underlined the primacy of EC competences. ${ }^{11}$ Former Article $47 \mathrm{EU}$ in particular aimed to protect the acquis

\footnotetext{
${ }^{9}$ Action brought on 11 March 2010 - European Parliament v. Council, Case C-130/10.

${ }^{10}$ For a more detailed analysis, see: P. Van Elsuwege, "EU External Action after the Collapse of the Pillar Structure: In Search of a new Balance between Delimitation and Consistency", 47CML Rev. (2010), pp. 9871019.

${ }^{11}$ See ex Article 47 EU in conjunction with ex Art. 1 (3) and 2 EU.
} 
communautaire against any encroachment on the part of the EU Treaty. ${ }^{12}$ In the ECOWAS judgment, the ECJ therefore found that for measures pursuing two aims which are inextricably linked without one being incidental to the other - in this case development cooperation and CFSP - priority should be given to the non-CFSP legal basis. Whenever an act could be adopted on the basis of the EC Treaty it turned out impossible to adopt an act with a similar content on the basis of the EU Treaty, irrespective the nature of the Community competences. $^{13}$

The new provisions on EU external action, introduced with the Treaty of Lisbon, have far-reaching implications for the existing case law and significantly affect the previous delimitation rules. First, the presumption in favour of using non-CFSP powers whenever possible is no longer valid. The CFSP is elevated to an equal level of protection as a result of Article 40 TEU in combination with Article 1 (3) TEU. ${ }^{14}$ Second, as a result of competence overlaps and the intertwined character of different foreign policy areas, the Court's traditional analysis of the 'aim and content' of a measure is not well-suited to distinguish between CFSP and non-CFSP actions. The interconnection between the EU's external policies is emphasized in Article 21 TEU, which includes a comprehensive list of objectives for the entire range of EU external action, and in Article 23 TEU, which states that the EU's activities in the field of CFSP are guided by the general principles and objectives of EU external action as a whole. In line with this approach, Article 24 (1) (ex 11, as amended) TEU no longer includes any references to CFSP objectives and bluntly states that:

“[T]he Union's competence in matters of common foreign and security policy shall cover all areas of foreign policy and all questions relating to the Union's security, including the progressive framing of a common defence policy that might lead to a common defence."

In the absence of specific CFSP objectives, it seems particularly difficult to apply a centre of gravity test. Hence, the question is how the Court can delineate between CFSP and non-CFSP external action with regard to issues such as terrorism and organised crime, where it is particularly difficult to draw a distinction between the internal and external aspects of the EU's security. In other words, when do measures essentially belong to the EU's counterterrorism policy in order to establish an AFSJ and when do they mainly aim to promote international peace and security as part of the CFSP? Or, to give another example, under which circumstances can Member States derogate from the general right to the protection of personal data as laid down in Article 16 TFEU ${ }^{15}$ Those questions have significant

\footnotetext{
${ }^{12}$ Case C-91/05, Commission v. Council (ECOWAS), [2008] ECR I-3651, para. 31-33; Dashwood, “Article 47 TEU and the relationship between first and second pillar competences” in Dashwood and Maresceau (Eds.), Law and Practice of EU External Relations (Cambridge, 2008), pp. 70-103.

${ }^{13}$ Case C-91/05, supra note 12 , para 58-62; Van Elsuwege, “On the Boundaries between the European Union's First Pillar and Second Pillar: A Comment on the ECOWAS judgment of the European Court of Justice”, 15 Columbia Journal of European Law (2008), 531-548.

${ }^{14}$ According to Article 1(3), the TEU and TFEU have the same legal value.

15 Article 39 TEU provides that, in derogation of Article 16 TFEU, the Council can adopt a special decision laying down the rules relating to data protection and the free movement of those data when the Member States
} 
implications as decisions which are directly concerned with CFSP are a matter for the Council alone, without any involvement of the European Parliament, whereas counterterrorism measures and general data protection rules are for co-decision between the Council and the Parliament. Moreover, the Court of Justice has no jurisdiction with respect to CFSP acts, with the exception of monitoring compliance with Article 40 TEU and to review the legality of sanctions adopted against individuals. ${ }^{16}$

That the question about the delimitation between situations falling under the AFSJ or the CFSP is not merely an academic discussion is clearly illustrated with a pending interinstitutional conflict between the European Parliament and the Council on the correct legal basis for the adoption of restrictive sanctions against individuals linked with Al-Qaida, the Taliban and Usama bin Laden (cf. infra). ${ }^{17}$ In order to fully understand the background of this case, it is necessary to evaluate the changes brought by the Treaty of Lisbon in this respect.

\section{The adoption of restrictive sanctions against individuals in the pre-Lisbon constellation: a pragmatic approach}

Before the entry into force of the Treaty of Lisbon on 1 December 2009, the primary legal framework of the EU did not include any explicit provisions for the adoption of sanctions against individuals. Hence, the Union's sanctions regime developed in practice on the basis of an expansionist use of the provisions regarding economic sanctions against third states. Pursuant to old Article 301 EC, the interruption or reduction, in part or completely, of economic sanctions with one or more third countries required a prior Common Position or Joint Action adopted under the CFSP and was to be decided by the Council on the basis of qualified majority voting and on a proposal from the European Commission. In addition, Article 60 (1) EC provided for a specific legal basis allowing the Council to adopt "in the cases envisaged in Article 301 [...] the necessary urgent measures on the movement of capital and on payments as regards the third countries concerned”. Hence, the EU's pre-Lisbon sanctions regime implied a two-stage process, starting with the adoption of a CFSP act and, depending on the nature of the measure and the division of competences, implementation on the part of the Member States and/or the European Community. Issues such as travel restrictions, diplomatic sanctions and arms embargoes ${ }^{18}$ required direct Member State action whereas import and export restrictions, a ban on financial and technical assistance, asset

\footnotetext{
are acting in the field of CFSP. On the unclear relationship between Article 39 TEU and Article 16 TFEU, see: House of Lords, Select Committee on European Union, Tenth Report, 26 February 2008, http://www.publications.parliament.uk/pa/ld200708/ldselect/ldeucom/62/6212.htm.

${ }^{16}$ Article 24 TEU

${ }^{17}$ Action brought on 11 March 2010 - European Parliament v. Council, Case C-130/10.

${ }^{18}$ On the basis of Article 346 TFEU (ex Art. 296 TEC), Member States may take adopt measures which are connected with the production of or trade in arms, munitions and war material.
} 
freezes and a ban on investment and credit, implied the adoption of a Community regulation on the joint legal basis of Articles 301 and 60 EC. ${ }^{19}$

Significantly, both Articles 301 and 60 EC only referred to "third countries" but remained silent on the possibility to adopt targeted sanctions against individuals. In the Minin case, an associate of former Liberian president Charles Taylor argued that those articles could, therefore, "not constitute an adequate legal basis for the purposes of adopting punitive or preventative measures affecting individuals and producing direct effect on them" ${ }^{20}$ The Court of First Instance, however, concluded that the restrictive measures adopted against Charles Taylor and his associates had "a sufficient link with the territory or the rulers of Liberia" to be regarded as "seeking to interrupt or reduce, in part or completely, economic relations with a [...] third country". ${ }^{21}$ Also in later judgments, both the Court of First Instance and the Court of Justice accepted that "the adoption of measures against a third country may include the rulers of such a country and the individuals and entities associated with them or controlled by them, directly or indirectly". ${ }^{22}$ Even a bank can fall within this definition when there is a link with the aim to put pressure on a third state. This was, for instance, the case with sanctions against Iran, which included the freezing of funds of banks suspected of providing financial and technical assistance for the nuclear and missile-development programme of this country. ${ }^{23}$

The limits of this far-reaching interpretation of the notion "economic sanctions against a third state" became obvious in the context of the EU's counter-terrorism policy. The revision of sanctions against persons and entities associated with Osama bin Laden, AlQaeda, and the Taliban, following the fall of the Taliban regime in Afghanistan in 2002, no longer provided for a link with the governing regime of a third country. ${ }^{24}$ In the absence of a specific legal basis for this new type of targeted sanctions, the Council adopted the amended regulation on the joint legal basis of Articles 60, 301 and 308 EC. The addition of the “flexible legal basis" or "supplementary competence” of Article 308 EC (now Art. 352 TFEU), turned out to be particularly controversial. The use of this provision was a popular solution to complement the limited express provisions on the external relations of the European Economic Community in the early stages of the European integration process. In the pre-Maastricht period, its combination with ex Article 113 EEC (now 207 TFEU) on common commercial policy was particularly fruitful for the conclusion of economic and co-

\footnotetext{
${ }^{19}$ A good example of the EU's sanctions regime in the pre-Lisbon period concerns the restrictive measures adopted against Burma/Myanmar in 2006/2007. See: M. Cremona, “EC Competence, 'Smart Sanctions' and the Kadi Case”, Yearbook of European Law (2009), p. 565.

${ }^{20}$ CFI, Case T-362/04, Leonid Minin v. Commission [2007] ECR II-2003, para. 59.

${ }^{21}$ Ibid., para. 72.

${ }^{22}$ ECJ, Joint Cases C-402/05 P and C-415/05 P, Kadi and Al Barakaat, [2008] ECR I-6351, para. 61.

${ }^{23}$ Joined Cases T-246/08 and T-332/08, Melli Bank plc v. Council, [2009] ECR II-2629, para. 69.

${ }^{24}$ Significantly, the initial UN resolutions requiring all States to freeze funds and other assets owned by the Taliban, Osama bin Laden and the Al-Qaeda organization were implemented in the EU by means of CFSP Common Positions and EC Regulations based on Articles 301 and 60 (1) EC. See: Common Position (CFSP) 1999/727, OJ (1999) L 294/1 and Council Regulation (EC) 337/2000, OJ (2000) L 43/1 and Common Position (CFSP) 2001/154, OJ (2001) L 57/1 and Council Regulation (EC) 467/2001, OJ (2001) L 67/1.
} 
operation agreements with third countries. ${ }^{25}$ However, the use of this provision was not without limitations. It could only be used when no other articles of the treaty gave the institutions the necessary powers to adopt the measure at stake and when Community action proved necessary to attain, in the course of the operation of the common market, one of the objectives of the Community. The latter preconditions complicated its use for the adoption of restrictive measures against individuals. This was clearly illustrated In Kadi, where the Court of First Instance, the Advocate General and the Court of Justice all came to different conclusions about the legal basis for adopting smart sanctions against non-state actors.

According the CFI, Article 308 EC could, in itself, not be used to pursue the safeguarding of international peace and security, i.e. an objective of the European Union and not of the European Community. However, in combination with Articles 60 and 301 EC this was deemed to be possible. Despite the coexistence of the Union and the Community as "integrated but separate legal orders", the explicit bridge between the two foreseen in Articles 60 and 301 EC was, in the opinion of the CFI, sufficient to use Article 308 EC in order to extend the scope of application of the latter provisions. ${ }^{26}$ The Advocate General, for his part, suggested a broad interpretation of Articles 60 and 301 EC alone as a sufficient basis for all types of economic sanctions. ${ }^{27}$ The ECJ, however, ruled out this option by referring to the text of those provisions and by pointing out that the "essential purpose and object" of the contested regulation was the fight against terrorism and not the adoption of economic sanctions against a third state. It also rejected the reasoning of the CFI that Article 308 EC could be used in combination with Articles 60 and 301 EC to achieve CFSP objectives derived from the EU Treaty. Nevertheless, it accepted that this combination of legal grounds was possible for other reasons. The objective to ensure the efficient use of a Community instrument to implement restrictive measures of an economic nature as well as the link of those measures with the operation of the common market explained, in the view of the ECJ, why the Al-Qaida Regulation was adopted on the correct legal basis of Articles 60, 301 and 308 EC together.

The combination of Articles 301, 60 and 308 EC provided a pragmatic solution to the absence of a specific competence for the adoption of sanctions against private individuals but could not avoid the impression that this practice went beyond the clear wording and objectives of those provisions. ${ }^{28}$ Moreover, a remaining problem concerned the lack of Community competences to adopt restrictive measures against individuals and terrorist organizations whose activities are wholly internal to the EU (so-called 'home terrorists'). ${ }^{29}$ The latter do not fall within the scope of CFSP and, therefore, the EU institutions could not

\footnotetext{
${ }^{25}$ See: M. Maresceau, “Bilateral Agreements Concluded by the European Community”, The Hague Academy of International Law Recueil des Cours 309 (2004), p. 187.

${ }^{26}$ CFI, T-315/01, Kadi v. Council and Commission, [2005] ECR II-3649, para. 123-125.

${ }^{27}$ AG Maduro in Case C-402/05 P, Kadi v. Council and Commission, para. 11-16.

${ }^{28}$ For a critical analysis of the Court's approach, see: C. Eckes, EU Counter-Terrorist Policies and Fundamental Rights. The Case of Individual Sanctions (Oxford, Oxford University Press, 2009), pp. 78-126.

${ }^{29}$ A clear example is that of Segi, an alleged terrorist organization fighting for Basque independence. See: Case C-355/04, Segi and others v. Council ECR [2007] I-1657.
} 
rely on the bridge between Community and Union competences to adopt implementing measures on the basis a Community regulation. In relation to 'home terrorists', the Council could only rely on third pillar instruments (police and judicial cooperation in criminal matters) without having a possibility to introduce direct legal consequences such as the freezing of assets and bank accounts. This type of action remained a competence of the individual Member States. ${ }^{30}$ In other words, the EU's pillar structure significantly complicated the efficient implementation of targeted sanctions in the pre-Lisbon period.

\section{A double explicit legal basis for the adoption of restrictive measures against individuals after Lisbon}

In an attempt to update the treaties to the new practice of smart sanctions, the Treaty of Lisbon explicitly foresees in the adoption of restrictive measures against individuals and nonState actors in Articles 75 TFEU (ex Art. 60 EC) and 215 (2) TFEU (ex. 301 EC). Whereas former Articles 60 and 301 EC operated as Siamese twins for the adoption of economic sanctions, new Articles 75 TFEU and 215 TFEU no longer include any cross-reference. To the contrary, both provisions have a different aim and function within the legal framework of the Union. Article 75 TFEU allows for the adoption of measures necessary to achieve the objectives of the Area of Freedom, Security and Justice (AFSJ), as regards preventing and combating terrorism and related activities. It provides an explicit legal basis for "administrative measures with regard to capital movements and payments, such as the freezing of funds, financial assets or economic gains belonging to, or owned or held by, natural or legal persons, groups or non-State entities”. In other words, it is a legal basis of its own right, which remedies the former impossibility to adopt autonomous financial sanctions against EU-internal terrorists (cf. supra). Article 215 TFEU, on the other hand, belongs to Part V of the TFEU on the Union's external action and allows for the implementation of CFSP decisions. Of particular importance are the procedural differences for the adoption of smart sanctions under the respective provisions. With regard to Article 215 (2) TFEU, a unanimously adopted CFSP decision is implemented by qualified majority in the Council on a joint proposal from the High Representative and the Commission. The European Parliament only has to be informed about the adopted measures. The situation is different under Article 75 TFEU where the Council and the European Parliament act in accordance with the ordinary legislative procedure, and without a prior CFSP decision. ${ }^{31}$

The legal complexities resulting from the ambiguous relationship between Articles 75 and 215 (2) TFEU became obvious in the context of the amendments to Regulation 881/2002/EC imposing restrictive measures directed against certain persons and entities associated with Osama bin Laden, the Al-Qaida network and the Taliban. In the wake of the Kadi judgment of

\footnotetext{
${ }^{30}$ E. Spaventa, "Fundamental Rights and the Interface between the Second and Third Pillar", in: A. Dashwood and M. Maresceau (eds.), Law and Practice of EU External Relations. Salient Features of a Changing Landscape (Cambridge, CUP, 2008), p. 132.

31 The ordinary legislative procedure is laid down in Article 294 TFEU and principally implies that the Council and the European Parliament co-decide on a proposal from the Commission.
} 
the ECJ, the Commission proposed to adopt those amendments on the basis of Articles 60, 301 and 308 EC. $^{32}$ Following the entry into force of the Treaty of Lisbon, the Commission announced that the proposal was to be adopted on the single legal basis of Article 215 (2) TFEU implying that the European Parliament was no longer to be consulted on the adoption of sanctions that relate to individuals. ${ }^{33}$ Immediately, the Committee on Legal Affairs of the European Parliament contested this course of events and suggested Article 75 TFEU as the proper legal basis for the proposed regulation "since the objective is preventing and combating terrorism and related activities by non-State entities". ${ }^{34}$ This position was later confirmed in a European Parliament resolution ${ }^{35}$ and resulted, after the adoption of Council Regulation No 1286/2009 on the basis of Article 215 (2) TFEU, ${ }^{36}$ in an action for annulment before the Court of Justice. ${ }^{37}$

\section{Potential solutions to inter-institutional conflicts about the legal basis for the adoption of restrictive sanctions against individuals}

One option to solve the above mentioned dilemma is to treat the CFSP as a lex generalis, which should be used only when action under a more specific provision (lex specialis) is not possible. ${ }^{38}$ Taking into account that the scope of Article 75 TFEU is more defined, relating to capital movements and payments, and is restricted to individuals, whereas Article 215 TFEU provides for all types of restrictive measures and also measures against third countries, this model suggests that Article 75 TFEU and not Article 215 (2) TFEU is the appropriate legal basis for amending Regulation 881/2002 EC. However, the problem is that this interpretation reintroduces a hierarchic relationship which is difficult to reconcile with the clear language of Article 40 TEU. It is, in other words, hard to see the added value of the new subparagraph protecting the CFSP against encroachment from other Union competences in comparison to the situation under old Article $47 \mathrm{EU}$. The Lisbon formulation of this provision would then only be symbolic without real legal consequences.

\footnotetext{
32 Proposal for a Council Regulation amending Regulation (EC) No 881/2002 imposing certain specific restrictive measures directed against certain persons and entities associated with Osama bin Laden, the Al Qaida network and the Taliban, COM (2009) 187 final, 22 April 2009.

${ }^{33}$ Communication from the European Commission to the European Parliament and the Council, "Consequences of the entry into force of the Treaty of Lisbon for ongoing interinstitutional decision-making procedures”, COM (2009) 665 final, 2 December 2009.

${ }^{34}$ European Parliament Committee on Legal Affairs, Opinion on the legal basis of the proposal for a Council Regulation amending Regulation (EC) No 881/2002 imposing certain specific restrictive measures directed against certain persons and entities associated with Osama bin Laden, the Al-Qaida network and the Taliban, JURI_AL(2009)430917, 4 December 2009, p. 8.

${ }^{35}$ European Parliament resolution of 19 December 2009 on restrictive measures directed against certain persons and entities associated with Usama bin Laden, the Al-Qaida network and the Taliban, in respect of Zimbabwe and in view of the situation in Somalia, OJ (2010) C 286 E/5.

${ }^{36}$ Council Regulation (EU) No 1286/2009 of 22 December 2009 amending Regulation (EC) No 881/2002 imposing certain specific restrictive measures directed against certain persons and entities associated with Osama bin Laden, the Al-Qaida network and the Taliban, O.J. 2009, L 346/42.

${ }^{37}$ Action brought on 11 March 2010 - European Parliament v. Council, Case C-130/10.

${ }^{38}$ M. Cremona, "Defining Competence in EU External Relations: Lessons From the Treaty Reform Process" in Dashwood and Maresceau (Eds.), Law and Practice of EU External Relations (Cambridge, 2008), p. 46.
} 
An alternative interpretation is that Article 215 TFEU, as part of the EU's external action, is used as a legal basis for sanctions against third states and persons engaged in activities outside the EU whereas Article 75 TFEU can be used exclusively for adopting measures against persons who are active inside the EU. This distinction reflects the old differentiation between sanctions adopted under the second and third pillar respectively (cf. supra). Moreover, it is true that the provisions regarding the AFSJ essentially concern the EU's internal security whereas the CFSP deals with the EU's external security situation. In practice, however, it appears very difficult if not impossible to distinguish between internal and external aspects of security. Terrorist organisations do not stop at the borders of the Union or its Member States and often have links all around the globe. The Al Qaida network and its alleged links with terrorist attacks in Spain and the United Kingdom provide a perfect example. At the least, it is arguable that terrorist organisations operating from outside the Union not only threaten the international peace and security but also the internal area of freedom, security and justice. Hence, any distinction on the basis of the internal or external dimensions of the targeted sanctions appears somewhat artificial.

A more appropriate solution could be to distinguish between two types of sanctions against individuals suspected of terrorist activities. In this scenario, Article 75 TFEU serves as the legal basis for sanctions adopted in the context of the EU's autonomous counter-terrorism strategy whereas Article 215 TFEU would constitute a lex specialis for financial sanctions based on UN-lists. ${ }^{39}$ This option has the advantage of clarity but nothing in the wording of Article 215 TFEU restricts its application to the implementation of UN Security Council resolutions. The only precondition is the adoption of a decision falling within the scope of CFSP. Also autonomous EU actions against terrorists operating outside the EU's borders have a foreign policy link which bring them at least potentially within the scope of Article 215 TFEU. This would limit the use of Article 75 TFEU to autonomous financial sanctions against EU-internal terrorists.

Based upon a comparison of the scope rationae materiae of Articles 75 and 215 TFEU, it may also be argued that the former provides a legal basis to adopt sanctions in the context of the EU's counter-terrorism policy whereas the latter is connected to the situation prevailing in a given third country. This interpretation suggests that Article 215 (2) TFEU codifies the Minin line of case law allowing for sanctions against persons having a sufficient link with the territory or the rulers of a given country (cf. supra). The observation that the European Parliament challenges only the sanctions against the Al-Qaida network but not Council Regulation 356/2010 imposing restrictive sanctions against certain natural and legal persons, entities and bodies in Somalia, reflects this approach. Taking into account that the application of Article 75 TFEU is limited to the prevention and combating of terrorism in order to establish an AFSJ, this distinction appears logical. On the other hand, terrorism is a volatile concept. For instance, the persons and entities listed in the EU sanctions Regulation against Somalia are all related to Al-Shabaab, which has recently been designated as a

\footnotetext{
${ }^{39}$ Eckes, supra note 28, p. 123.
} 
'terrorist organization' in many countries and which is suspected of close links with $\mathrm{Al}$ Qaida. ${ }^{40}$ Or, to give another example, the Taliban used to belong to the official government of Afghanistan but are now linked together with Usama bin Laden and Al Qaida in the context of the EU's counter-terrorism strategy. In order words, the borderline between terrorist activities and other acts threatening the (international) peace and security is not always very clear and may evolve.

Proceeding from the interconnection between terrorism and security and between the internal and external dimensions of security, it is at least arguable that the restrictive sanctions against persons linked with Usama bin Laden, Al Qaida and the Taliban pursue both the objectives of the AFSJ and of the CFSP. Because both dimensions appear to be equally important and cannot be separated in practice, the question is whether recourse to a dual legal basis might be an appropriate solution. According to the Court's established case law, recourse to a dual legal basis can exceptionally provide a way out on the condition that procedures laid down for the respective legal bases are not incompatible and do not undermine the rights of the European Parliament. ${ }^{41}$ Whereas a combination between qualified majority voting and unanimity in the Council appears to be excluded, ${ }^{42}$ the Court's conclusion in Opinion 1/08 and International Fund for Ireland revealed that this rule is not absolute. ${ }^{43}$

Taking into account the very unusual provision of Article 40 TEU, which prescribes a balance between the procedural and institutional characteristics of the EU's CFSP and nonCFSP external competences as well as the duty of consistency (Art. 7 TFEU), a compromise solution of a double legal basis including CFSP and non-CFSP provisions seems, therefore, not by definition excluded. Such a compromise would, on the one hand, respect the external competences of the European Parliament and, on the other hand, confirm the principle of unanimous decision-making in the Council.

The different roles of the European Parliament in the decision-making process (codecision with the Council in the context of Article 75 TFEU and only a right of information under Article 215 TFEU) is not problematic either. On several occasions, the Court confirmed that a legal basis providing for a limited or even no formal role for the Parliament is compatible with the co-decision procedure. ${ }^{44}$ The Court argued that such a combination reinforces the democratic legitimacy of decision-making and ignored the implications for the Council, which is deprived of its exclusive legislative competence. ${ }^{45}$ Recourse to a double legal basis would at least have the advantage of respecting the envisaged balance between the

\footnotetext{
${ }^{40}$ Al-Shabaab is designated as a terrorist organization in the United States, Australia, Canada and the United Kingdom. See: http://www.nctc.gov/site/groups/al_shabaab.html.

${ }^{41}$ Case C-300/89, Titanium dioxide [1991] ECR I-2867, para. 17-21; Case C-178/03 Commission v. Parliament and Council [2006] ECR I-107, para. 57.

${ }^{42}$ Case C-338/01, Commission v. Council [2004] ECR I-4829, para. 58.

43 S. Adam and N. Lavranos, Case note on Opinion 1/08, 47 CML Rev. (2010), p. 1535; Case C-166/07, European Parliament v. Council of the European Union [2009] ECR I-7135, with case not of T. Corthaut, “Institutional Pragmatism or Constitutional Mayhem?”, CMLRev. (2011), pp. 1271-1296.

${ }^{4}$ Case C-178/03, Commission v. Parliament and Council [2006] ECR I-107, para. 59; Case C-155/07, Parliament v. Council [2008] ECR I-8103, para. 77-79.

${ }^{45}$ See in this respect Opinion of Advocate General Kokott in Case C-178/03, para. 61 and Case C-155/07, para. 89.
} 
EU's CFSP and non-CFSP competences as laid down in Article 40 TEU. Moreover, any other solution, i.e. the adoption of the restrictive measures on the single legal basis of either Article 75 TFEU or Article 215 TFEU, seems to be based on artificial criteria which are difficult to reconcile with the objective of policy coherence in the EU's external action.

\section{Conclusion}

The rules for the adoption of restrictive sanctions against individuals or non-State actors clearly illustrate the constitutional complexities of the European Union. In the pre-Lisbon period, the implementation of the Union's counter-terrorism strategy and UN Security Council resolutions required actions under the three pillars and from the Member States depending upon the specific nature of the sanctions at stake. Economic sanctions, in particular, turned out to cut across the Union's pillar structure requiring a combination of CFSP and Community measures. The evolution towards a practice of targeted sanctions against individuals and non-State actors required pragmatic solutions. In this respect, the Court of Justice played a crucial role in clarifying the division of competences between the different institutional actors. First, based upon a purposive interpretation of the provisions on economic sanctions against third states, the Court accepted that also measures against the rulers of those states as well as individuals and entities associated with them or controlled by them could be adopted. Second, in Kadi and Al Barakaat, the ECJ clarified that also measures against non-State actors could be adopted by making use of the so-called flexible legal basis (ex Art. 308 EC) in combination with the rules on economic sanctions against third states (ex Art. 60 and 301 EC). Third, for sanctions against non-State actors operating inside the Union, the competences on police and judicial cooperation formed the appropriate legal basis even though the treaties did not allow for any legislative action in this area and thus required action by the Member States.

For a number of reasons, the pre-Lisbon pragmatic approach turned out to be unsatisfactory. In particular, the absence of a specific legal basis to target non-State actors constituted an important hurdle for the effective implementation of UN Security Council Regulations. The exceptional use of a triple legal basis made the adoption of the required measures possible but nevertheless seriously complicated the decision-making procedure. Moreover, the distinct procedures for the adoption of sanctions within the framework of the Union's CFSP, implemented on the basis of binding Community instruments, and within the context of the EU's autonomous strategy against internal terrorist groups, which required implementation at the Member State level, were difficult to justify in terms of policy coherence.

In order to remedy the identified problems, the Treaty of Lisbon introduced a specific legal basis for the adoption of restrictive measures against individuals under both the chapter on the AFSJ and for the implementation of the CFSP. Whereas this was a logical evolution in order to provide the Union with the necessary powers for an effective implementation of its counter-terrorism policy, on the one hand, and for the implementation of UN Security Council 
resolutions, on the other hand, the different decision-making procedures under both policy areas raise new challenges of coherence. In particular, the absence of a formal role for the European Parliament in the area of CFSP in comparison to its position as a co-legislator with regard to the AFSJ increases the potential for inter-institutional litigation after Lisbon. This is clearly illustrated with the dispute about the legal basis for the amendment of Regulation 881/2002/EC imposing restrictive sanctions against certain persons and entities associated with Usama bin Laden, the Al-Qaida network and the Taliban. Proceeding from the new legal framework for EU external action and, in particular, in light of the new delimitation rule of Article 40 TEU, it is argued that recourse to a dual legal basis provides a possible satisfactory solution to this type of inter-institutional conflicts.

Finally, irrespective the institutional complexities of competence delimitation between the AFSJ and the CFSP, efficient EU action essentially requires close co-operation and understanding among the institutions. An important instrument to reach this objective is provided under Article 295 TFEU:

"The European Parliament, the Council and the Commission shall consult each other and by common agreement make arrangements for their cooperation. To that end, they may, in compliance with the Treaties, conclude interinstitutional agreements which may be of a binding nature".

For instance, the conclusion of an interinstitutional agreement between the European Parliament and the Council regarding the coordination of legal safeguards required for the adoption of restrictive measures under both Articles 215 and 75 TFEU would certainly contribute to the coherence between the EU's activities under the CFSP and AFSJ.

Proceeding from the unity of the EU legal order, the increased linkage between CFSP and non-CFSP instruments provides another pragmatic solution for what Piet Eeckhout calls the "overall sin of EU external action". ${ }^{46}$ Support for such a pragmatic modus vivendi can be implicitly found in the ECOWAS judgment where the Court annulled the implementing CFSP Council Decision while leaving the original CFSP Joint Action untouched. In the absence of any direct jurisdiction on the duty of consistency at that time, the Court pointed at the inclusion of a reference to "the need of consistency of the Union's activities in the field of small arms and light weapons" in the contested CFSP acts to conclude that "the objectives of the contested Joint Action can be implemented both by the Union, under Title V of the EU Treaty and by the Community, under its development cooperation policy". ${ }^{47}$ Arguably, this approach of a comprehensive CFSP act leading to both CFSP and non-CFSP implementing measures may help to find a balance between the requirement of consistency and the principle of mutual non-affection laid down in Article 40 TEU. ${ }^{48}$

In other words, even though the division between CFSP and non-CFSP external action continues to complicate the coherence of the EU's activities, the Treaty of Lisbon also offers

\footnotetext{
${ }^{46}$ Eeckhout, P., External Relations of the European Union. Legal and Constitutional Foundations (Oxford, 2004), p. 145.

${ }^{47}$ Case C-91/05, Commission v. Council (ECOWAS) [2008] ECR I-3651, para. 86-88.

${ }^{48}$ Van Vooren, B., “The Small Arms Judgment in an Age of Constitutional Turmoil”, 14 EFA Rev. (2009), pp. 244-248.
} 
sufficient instruments and incentives to overcome the institutional battering. ${ }^{49}$ However, it remains to be seen to what extent the EU institutions and Member States are willing to overcome the inherent tensions resulting from the horizontal and vertical division of competences as laid down in the Treaties.

\footnotetext{
${ }^{49}$ See also the contribution of Florian Tauner to this conference.
} 